\title{
Self-efficacy beliefs of at-risk students in Malaysian Secondary Schools.
}

\begin{abstract}
Self-efficacy beliefs determine how people feel, think, motivate themselves and behave. A strong sense of efficacy enhances human accomplishment and personal well being in many ways. Selfefficacy is defined as people's beliefs about their capabilities to produce designated levels of performance which have influence over events that affect their lives (Bandura, 1994). A study was conducted on 688 Form Four students from 25 at risk schools located in 5 zones in Malaysia, to examine their self-efficacy beliefs in learning mathematics and English Language. Findings showed that the at risk students have low self-efficacy in Mathematics and English Language. Positive and significant correlations were found between self-efficacy in mathematics and English with achievemnet in the Lower Secondary Examination. Female students were found to have higher self-efficacy beliefs in English Language and mathematics compared to males. The implications of the findings are discussed in terms of learning opportunities for at risk students.
\end{abstract}

Keyword: At-Risk Students; Self-Efficacy Beliefs; Academic Achievement. 